\title{
TOURIST GUIDES, COVID 19 AND SURVIVAL MECHANISMS IN SOUTH AFRICA
}

\author{
Fisokuhle MBATHA \\ University of Johannesburg, School of Tourism \& Hospitality, College of Business and Economics, South Africa, e-mail: fjmbatha@ gmail.com \\ Vyasha HARILAL \\ University of Johannesburg, School of Tourism \& Hospitality, College of Business and Economics, South Africa, e-mail: vyashah@uj.ac.za
}

Tembi Maloney TICHAAWA*

University of Johannesburg, School of Tourism \& Hospitality, College of Business and Economics, South Africa, email: tembit@uj.ac.za

Citation: Mbatha, F., Harilal, V., \& Tichaawa, T.M. (2021). TOURIST GUIDES, COVID 19 AND SURVIVAL MECHANISMS IN SOUTH AFRICA. GeoJournal of Tourism and Geosites, 39(4spl), 1461-1472. https://doi.org/10.30892/gtg.394spl17-790

\begin{abstract}
The main aim of this research was to investigate the survival mechanisms employed by tourist guides in the context of the Covid 19 Pandemic. A mixed method research design was adopted, using in-depth interviews with key tourism informants and surveys administered to tourist guides in Gauteng. A total of five key informant interviews and two hundred surveys were collected at the end of the data collection period. Key findings indicate that many tourist guides were unable to access the aforementioned fund and had to implement their own short and long-term survival mechanisms. In many cases, various cost cutting measures were implemented and the utilization of personal savings and loans. Other guides temporarily engaged in different employment to secure an income. This study presents policy and systemic recommendations, which, if accepted and implemented, could assist the reignition of the tourist guide profession post-pandemic and ensure they form part of the tourism sector recovery trajectory. Additionally, further research on tourist guides in South Africa needs to be conducted, to fully understand the various aspects of this profession in the country.
\end{abstract}

Key words: tourism crises, tourist guide, COVID-19, destination resilience and recovery, TRF

$* * * * * *$

\section{INTRODUCTION}

The COVID-19 induced pandemic had an immediate and long-lasting effect on the tourism sector worldwide, affecting all stakeholders within the tourism value chain (Jones and Comfort, 2020). With the onset of the global lockdown in March 2020, the tourism sectors of all destinations globally were brought to a standstill to restrict the spread of the COVID-19 virus. Before the pandemic, many countries had adopted the tourism sector to leverage the associated socio-economic growth and development impacts within destinations (Siakwah et al., 2019). This had been especially true for countries located in the global south, where, although many sectors were still developing, reliance on tourism as an economic contributor was significant, as it served as a method of sustaining the livelihoods of stakeholders (Venkatesh and Gouda, 2016), such as those of tourist guides. Resultantly, the impact of the pandemic on the tourism sector from its inception until present has been well documented (Gössling et al., 2020; Brouder et al., 2020; Seyfi et al., 2020; Rogerson and Rogerson, 2020; Bama and Nyikana, 2021). It is evident that the recovery of the industry, both globally and at national levels, is dependent on the safe and free flow of tourists into and within destinations. At this juncture, it is prudent to consider important enabling factors which would allow for such. There has been a significant amount of debate on the utility of vaccinations being used in conjunction with other safety measures for the safe reopening of the sector, with this being used as one of the primary strategies in reigniting cross-border travel (see Helble et al., 2021; Wang et al., 2021; Su et al., 2021). Not only has this been linked to uninhibited travel across national and international borders (Davidson, 2021; Sharun et al., 2021), but it has also been linked to reassuring tourists of health and safety measures taken, especially given the high level of interaction between tourists and stakeholders. This is an important consideration, as tourists' motivations to travel have changed, as have their needs when travelling (Kaewkitipong et al., 2021). As countries advanced in their vaccination rollout programmes, travel in certain regions of the world resumed, thus paving the way towards recovery. However, not all countries embarked on mass vaccination programmes at the same time. In fact, countries located in the global south did not have access to vaccine stock until the rollout in other countries was well underway. Thus, the initial steps towards recovery were skewed, with this trajectory being continued until present, having a direct impact on all tourism stakeholders.

The arrival of the COVID-19 virus in South Africa shone a spotlight on the tourism sector through the movement of people (Sigala, 2020), as the first confirmed case is thought to have originated from people entering the country after having initially contracted the virus elsewhere (Jones and Comfort, 2020). However, in addition to this, the spotlight on tourism stakeholders, such as tourist guides, ability to survive an unprecedented crisis was a cause for concern (Nyawo, 2020). The early response of the South African government to combat the spread of the disease, in the form of the nationwide lockdown, had (and continues to have) dire socio-economic impacts (Phillips, 2020; Dube, 2020). Although the hard lockdown in South Africa was lifted midway through 2020, the country continued to face the second COVID-19 wave

\footnotetext{
* Corresponding author
} 
towards the end of December 2020 and into the beginning of January 2021, which led to the adjusted COVID-19 alert level 3 lockdown being effected on the 28 December 2020 and with further adjustments introduced on 11 January 2021 by the President of the Republic of South Africa, Cyril Ramaphosa (BusinessTech, 2021). This cycle repeated itself mid-2021 when the country was placed under an adjusted alert level 3 with the arrival of the third wave of infections. Throughout this period, South Africa was placed on the red list for travel, thus preventing international tourists from visiting and significantly reducing the demand for tourism services like tourist guiding. Unfortunately, but predictably, the number of infections in the country is on the rise again, with indications that the country is on the precipice of the fourth wave of infections. Worsening this situation is the discovery of a new variant at present in the country, which has led to many countries placing South Africa on the red list for travel again (Smith, 2021a). This has had severe consequences for the tourism sector and many service providers, who were counting on the December international and domestic tourism trade as significant steps towards recovery and towards inspiring consumer confidence again. As the number of infections continues to rise in the country currently, it poses the possibility of regressive restrictions that would further inhibit the industry, potentially restricting domestic tourism as well. Tourism stakeholders' hopes for the survival and recovery of South Africa's tourism sector have been dampened, with hospitality associations voicing their extreme concern about the situation (Daniel, 2021). Current prospects for the complete reopening of the sector remain low, with many businesses, several of which are small to medium sized, already struggling to stay afloat, despite the government sponsored support packages (Smith, 2021a). Coupled with the high rate of unemployment in the country is an impact that the country can ill afford.

It is against this background that the current study is conceptualized. An aspect of the tourism industry that has suffered enormously is tour guides. Tour guides, who form an integral part of the tourism value chain (Chen et al., 2018; Nyahunzvi and Njerekai, 2013), will not begin to recover until the tourism sector, both domestic and international, reopens. Even upon reopening the sector in a post COVID era, the livelihood of tour guides will remain dependent on the willingness of people to engage in tourism activities and utilise their services. Such willingness may not be immediate, with the choice to travel being carefully considered against personal safety (Brouder, 2020; Sigala, 2020). Furthermore, as the global and national lockdowns have resulted in many people losing their incomes, the number of people financially able to engage in tourism activities could decrease significantly. A tour guide's role is essential within the tourism sector, involving travelling with tourists from their place of arrival to all places they would like to visit in South Africa. Furthermore, tourist guides play a key role in securing repeat visits from tourists and in maintaining a favorable destination image (National Department of Tourism [NDT], 2020; Nyawo, 2020). Despite being integral stakeholders within the tourism sector, there is relatively little known about who tourist guides are within the South African context. What is known points to the extreme vulnerability of tourist guides to the crisis, especially one as prolonged and unprecedented as the current one. Thus, the current study seeks to examine the impact of the COVID-19 induced crisis on tourist guides and the types of survival mechanisms that tourist guides have employed since the start of this crisis. Tourist guides' perceptions of the utility of government support measures are also examined. This study was carried out using a case study of registered tourist guides in the Gauteng region of South Africa.

\section{LITERATURE REVIEW}

\section{The tourism sector and tourism crises}

Prior to March 2020, the tourism sector enjoyed consecutive years of growth, surpassing that of other major industries. The sector was relied upon by many countries to boost socio-economic growth, especially by countries located in the global south (Sigala, 2020). Key strategic economic development from the tourism sector was linked heavily to the creation of employment for locals, having a knock-on social effect of improving their livelihoods and contributing to the alleviation of poverty (Siakwah et al., 2019). The tourism sector has also earned the title of a resilient sector, given its track record of recovery from previous crises that afflicted the sector. For example, the tourism sector was one of the first to begin to recover following the global recession that started in 2008. The sector also recovered from the damaging effects on the perceptions of safety and security following the 9/11 terrorist attacks in the United States of America and the slew of earthquakes and tsunamis that ravaged South Asian countries over the past two decades. Moreover, the sector has also recovered in the face of previous crises triggered by infectious diseases such as the Zika virus, MERS, and Ebola (Hall et al., 2020; Henderson, 2020; Ritchie and Jiang, 2019). Thus, the reputation of the sector as being a resilient one is well earned.

Although the sector has bounced back from previous crises admirably, there has been debate around when and how the sector could begin to recover from the current crisis (Sucheran, 2021). The goalpost is constantly shifting given the constantly changing situation, as well as the uneven global progress with the management of the crisis. The prolonged nature of the crisis is also a major difference between this and other crises that the tourism sector has weathered, thus casting uncertainty on a quick recovery (Iastremska and Kononova, 2021). The management of this crisis has shone a spotlight on crisis management in the sector, as well as resilience building. The latter is an extremely important aspect that can no longer be overlooked. The resilience of the sector determines how effectively tourism stakeholders can adapt to change to ensure their survival and how quickly they are able to bounce back (Jones and Comfort, 2020). Thus, it is imperative that the rebuilding of the tourism sector is modeled around the concept of resilience to reduce the vulnerability of tourism stakeholders in times of crisis (Cahyanto and Pennington-Gray, 2017).

\section{COVID-19 and the South African tourism sector}

Within the South African context, it was reported that the tourism industry was responsible for approximately $6.9 \%$ of the national gross domestic product (GDP) in 2019 and approximately $8.9 \%$ of the total employment in the country. However, with the onset of the COVID-19 induced pandemic, the tourism sector was plunged into crisis resulting in 
massive degrowth. In 2020, the sector's contribution to the national GDP reduced to $3.7 \%$ and the total employment to 6.5\% (World Travel and Tourism Council [WTTC], 2021). Additionally, it has been noted that due to global and national lockdown restrictions, the number of international and domestic tourist arrivals in the country has also significantly declined, thus reducing the demand for tourism services (Rogerson and Rogerson, 2021). The drastic reduction in these statistics provides an idea of the severe impact that the current crisis has had on all tourism stakeholders. Many tourism service providers in South Africa are small business owners, most of whom are without the capacity to survive acute shocks. Thus, from the beginning of this crisis until present, there has been mass job loss within the sector, with more forecasted should demand not increase soon (NDT, 2020).

Initially, tourism demand completely halted as a result of tourists' inability to travel. National and international borders were closed in an effort to prevent the spread of the virus (Bama and Nyikana, 2021). However, as these restrictions were lifted, other factors such as tourists changing needs and travel preferences, vaccination and quarantine requirements, and sundry travel bans began to dictate demand (Rogerson and Rogerson, 2021; Kim et al., 2021). It is established that tourists' needs and motivations play a significant role in their travel decisions. The COVID-19 virus changed tourists' needs, in many cases requiring stringent health and safety protocols to be instituted. Additionally, as the narrative around the existence of the virus progressed, adaptation and survival mechanisms incorporated the use of non-pharmaceutical measures such as social distancing, limiting the number of people in an area or space at once, contact tracing, the wearing of face masks, and the provision of sanitizer stations. The development of vaccines was a turning point, which allowed regional and international borders to slowly reopen and enabled tourists to travel on condition of vaccination status. The use of a vaccination passport and travel bubbles became a popular strategy towards the recovery of the sector (Sharun et al., 2021). However, as previously mentioned, given the uneven distribution of vaccines, not all destinations were able to embark on sector recovery, with the result that the global tourism industry was (and still is) characterised by destinations that are fully functional and those that are not. To add to this complex situation, the occurrence of virus strain mutations has resulted in a country like South Africa being placed on the red list for travel, banning and dissuading tourists from visiting (Daniel, 2021). This has led to severe set back within the industry and for tourism stakeholders, who are unable to survive in crisis mode for a prolonged period. Apart from this acute consequence, there has also been longer term damage that South Africa as a destination has suffered, from being labeled unsafe due to new, severe strains of the virus originating here. This type of sensationalist and incorrect reporting damages perceptions of the country, thereby demotivating tourists who travel to the area (NDT, 2021). In a country like South Africa, where international tourists from overseas source markets are key to adequate tourism demand (NDT, 2018) and hence the survival of small businesses, the significant reduction in tourist arrivals has taken its toll on small businesses and entrepreneurs in the country.

\section{Tourist guides and the South African context}

An example of a tourism stakeholder that had been detrimentally impacted by the reduction in tourist arrivals and the lockdown restrictions is tourist guides. Tourist guides play an important role in the tourism value chain (Chowdhary and Prakash, 2010), contributing to a destination's image by acting as hosts and chaperons for tourists (Chen et al., 2018; Nyahunzvi and Njerekai, 2013). Tourist guides share knowledge about places and space with tourists, guiding them in cultural sensitivity and towards authentic experiences within a destination (Huang et al., 2010; Feldman and Skinner, 2018). In many instances, tourist guides work within areas that they originate from, thus providing an insider perspective for tourists. Additionally, tourist guides act as an intermediary between locals and tourists, ensuring that locals are not downtrodden by tourists, which could consequently lead to the development of hostility towards them. Overall, tourist guides play an important role within the industry, which can scarcely be replaced and are often referred to as co-creators of experiences (Weiler and Black, 2015; Hu, 2007). However, despite this important role, there is only a limited amount of scholarship on tourist guides within the South African context.

The limited research that does exist is mostly focused on the analysis of the development of tourist guiding (Davids, 2008); conditions of employment for tourist guides in the South African tourism industry (see De Beer, 2011); the contradictions and contestation in policy for the training of tourist guides (see Gavron, 2002); status of employment of tourist guides in South Africa (see McIntyre, 2007); tourism and development issues in South Africa (see Rogerson and Visser, 2004); tourism, small firm development and empowerment (see Rogerson, 2004). While the existing recent research is not related to the current topic of the research, it does serve to contextualize certain prominent issues in this study, such as tourist guide legislation and instructional design for guiding tourists (see Smal, 1997); and status of tourist guide employment (see McIntyre, 2007). As previously discussed, the focus of this paper is on the impacts that tourist guides have borne since the onset of this pandemic and how these impacts have affected the survival of these stakeholders.

Tourist guides in South Africa commonly operate on a freelance basis, contracting to tour operators. It has been noted that despite missing out on the security of employment, freelance guides earn more than those employed on a fulltime basis. In both cases, the quality of guiding provided is important for the quality of the tourism experience (Nyawo, 2020) and can be linked to repeat visits or referrals to visit (Weiler and Ham, 2001b). The chance of repeat callback for freelance guides and the employment security of those permanently employed is related to the ability of the tourist guides to communicate clearly, coupled with their knowledge and experience (Chilembwe and Mweiwa, 2014). Freelance tourist guides constantly need to secure jobs to ensure the upkeep of their livelihoods. Thus, tourist guides work closely with tour operation businesses to ensure repeat work (De Beer et al., 2014). This arrangement also benefits tour operators who do not have a permanently employed guide within their operations. However, the lack of formal or contractual obligation places tourist guides in a precarious and vulnerable position, whereby they stand to lose to 
guiding opportunities when tour operator businesses are afflicted or when the industry deals with crisis (De Beer, 2011). The latter has, unfortunately, become a reality since March 2020.

Similar to many countries globally, financial and fiscal measures had been the immediate response of the government in assisting the tourism industry. In an effort to try and assist with immediate survival, the South African government made provision for a relief fund dedicated for use by tourist guides - the Tourist Guide Relief Fund. This was amongst other support mechanisms that were underscored by the government and made available to various stakeholders in the sector (NDT, 2021). Given the sudden onset of this crisis and its unprecedented nature, the goal of these support measures and programmes was to bridge the short-term survival of all stakeholders within the sector, to ensure that when tourism demand is reinstated, the supply capacity is also present. However, the accessibility of these support measures became problematic, with stakeholders reporting that administrative requirements prevented them from accessing the funds (see Plasket, 2021; Girma, 2021; Masihlelo, 2020). Another hurdle reported by stakeholders was the conditions of access - a matter that was ultimately taken under the advisement of the legal system (Smith, 2021b). According to the NDT's 2020/2021 annual report, the Tourism Relief Fund supported in excess of 4000 tourism and hospitality businesses (NDT, 2021). However, the details of this support have been flagged as problematic, with claims of corruption and misappropriation of funds (NDT, 2021). It is against this background that the current paper is set, with the primary aim to determine the survival mechanisms that tourist guides have adopted since the beginning of this pandemic. Additionally, given the lack of information on who tourist guides in South Africa are, this paper also provides a brief insight into the demographic profile of tourist guides who participated in this study. The demographic information also served a dual purpose in that it also contextualized the findings related to the primary aim of the paper.

\section{Background to study area}

This study was carried out with tourist guides located in the Gauteng province in South Africa. The rationale for this was centered on the popularity of the province as a domestic and international tourist destination, as well as the high concentration of tourist guides in the province. The South African tourism performance reports show that in 2019, the province was the most visited province by international tourists in South Africa, accounting for 3.5 million of the 10.2 million international visitors and accounting for R24.9 billion of the R81.2 billion total spent by international visitors (South African Tourism, 2019). While the overall visitor numbers in the country have dwindled by 71\% (Stats SA, 2021) as a result of the COVID-19 pandemic, due to the lockdown and travel restrictions, the province still presented a good study area, in that it is home to a combination of influential role players in the overall tourism industry and is amongst the provinces with the largest affiliation of tourist guides in the country (Ramphele, 2020).

\section{METHODOLOGY}

The current study employed a mixed method methodology, utilizing quantitative surveys to record the views and perceptions of tourist guides located in Gauteng province of South Africa, whilst qualitative in-depth interviews were held with key stakeholders in the tourism sector. The utilization of mixed methods is a common occurrence in tourism related research (Nunkoo, 2018; Iaquinto, 2018), as it provides the opportunity for in-depth interrogation of a topic, as well as provides a means for triangulation of the data collected (Levine, 2014; Creswell and Creswell, 2018). Data collection for this study was undertaken in two phases. Phase one was centered on conducting interviews with key tourism stakeholders with knowledge of the impact that COVID-19 has inflicted on the industry and tourist guides, as well as with stakeholders from tourist guiding organizations. Interview schedules consisting of open-ended questions were utilized to guide the interviews, with questions centered around the impact of the pandemic on the tourism sector and tourist guides, policy imperatives, and operational matters related to tourist guides and support mechanisms available to these stakeholders.

Key stakeholders interviewed were purposively chosen, owing to their knowledge of the impact that the current crisis has had on the tourism sector and tourist guides. Included in these respondents were representatives from the NDT (director of tourist guiding), the National Federation of Tourist Guides and Affiliates (NFTGA) (media liaison), the Gauteng Department of Economic Development (director of tourist guiding), CATHSSETA (education and training quality assurance specialist) and the Cradle of Humankind World Heritage Site (marketing director). Each of these key informants contributed meaningfully to this research. For example, stakeholders from the NDT and the Gauteng Department of Economic Development provided important information on the impacts of COVID-19 on the sector, as well as policy and support mechanisms available to tourist guides, both from a national and provincial perspective. Given that this study focused on tourist guides in the Gauteng province of South Africa, it was essential to gain the views of stakeholders with nuanced knowledge of the situation in the specific region. Additionally, the informant from the NFTGA and the Cradle of Humankind World Heritage Site provided information on key operational issues that tourist guides face, as well as issues that affect the profession of tourist guiding within the South African context. The informant from CATHSSETA was important in providing information on the skills and training that tourist guides are required to possess. Due to COVID-19 induced lockdown regulations at play during data collection, interviews were held online using teleconferencing software.

The information gained from the interviews was used in the construction of surveys, which were administered to tourist guides as phase two of the data collection. Similar to the interviews, surveys were administered through the use of an online survey link. The surveys consisted of a series of closed ended questions and Likert scale questions. The closed ended questions were aimed at collecting demographic data about the respondents, and the Likert scale questions were used to gauge tourist guides' perceptions on the impact that the current crisis has had on them, as well as on the utility of support mechanisms and programmes. Also, the survey included a screening question to ensure that the 
responses were from tour guides located in Gauteng. Data collection took place from February to June 2021. At the end of the data collection process, a total of five in-depth key informant interviews were conducted, and two-hundred surveys were completed. The Statistical Package for Social Sciences (SPSS) was used to analyse the quantitative data, generating descriptive statistics. The interviews were transcribed verbatim, and content analysis was subsequently carried out. This type of analysis was done to identify key themes that emanated from the data (Neuendorf, 2017). The data from both the surveys and interviews were triangulated, which aided in the verification of the findings (Nunkoo, 2018).

\section{RESULTS AND DISCUSSION}

\section{Demographic profile of tourist guides surveyed}

The important role that tourist guides occupy in the tourism sector has been noted, yet research on who these tourist guides are within the South African context is lacking. Demographic information reveals key information about tourist guides, which can be used to support these important tourism stakeholders strategically. Given the current COVID-19 induced context, such information has become critical in identifying the type of support required by tourist guides. As previously discussed, the COVID-19 induced pandemic and state of disaster in South Africa enabled the rollout of lockdown levels dependent on the number of COVID-19 infections in the country. The impact of the levels has taken its toll on the tourism sector, with tourism businesses having to either remained closed or open only partially in response.

The other major consequence of the various lockdowns has been the restrictions on the movement of people within the country, as well as into the country. Both domestic and international tourists in the country are served by tourist guides, and the absence of tourists is detrimental to their livelihoods. Thus, the current study undertook to determine the demographic profile of the tour guides who were surveyed in an effort to better understand the needs of tourist guides under the current circumstances. A total of 200 tourist guides from the Gauteng province were surveyed as part of this research. A summary of the demographic profile of these guides is presented in Table 1 below.

Table 1. Demographic profile of respondents

\begin{tabular}{|l|c|}
\hline Category & \% $(\mathbf{n}=\mathbf{2 0 0})$ \\
\hline Gender & \\
\hline Male & 59.5 \\
\hline Female & 38.0 \\
\hline I prefer not to disclose my gender & 2.5 \\
\hline Age & \\
\hline $23-35$ & 39.0 \\
\hline $36-45$ & 25.5 \\
\hline $46-64$ & 26.5 \\
\hline $65+$ & 9.0 \\
\hline Residential regions of tourist guides in Gauteng province & \\
\hline Johannesburg Metropolitan & 33.0 \\
\hline Tshwane Metropolitan & 20.5 \\
\hline Ekurhuleni Metropolitan & 16.5 \\
\hline Sedibeng District Municipality & 14.0 \\
\hline West Rand District Municipality & 16.0 \\
\hline Educational qualification of tourist guides & \\
\hline Undergraduate degree/diploma & 42.0 \\
\hline Senior Certificate & 35.0 \\
\hline Postgraduate degree & 11.0 \\
\hline No formal qualification & 10.0 \\
\hline Other (please specify) & 1.5 \\
\hline Career experience of tourist guides & 11.5 \\
\hline 1-3 years & 24.0 \\
\hline 3-5 years & 38.5 \\
\hline 5-10 years & 26.0 \\
\hline More than 10 years & \\
\hline
\end{tabular}

Table 2. Tourist guide classifications

\begin{tabular}{|l|c|}
\hline \multicolumn{1}{|c|}{ Category } & $\%$ (n= 200) \\
\hline Classification of work of tourist guides & \\
\hline Freelancer / self-employed & 67.5 \\
\hline Casual - part time employed & 13.5 \\
\hline Full time employed & 19.0 \\
\hline Qualification level of tourist guiding & \\
\hline NQF 2 & 32.0 \\
\hline NQF 4 & 67.0 \\
\hline Other (please specify) & 1.0 \\
\hline Category levels of tourist guiding & \\
\hline Site guide & $32.6 \%$ \\
\hline Provincial guide & $39.1 \%$ \\
\hline National guide & $28.3 \%$ \\
\hline Classification of tourist guiding & \\
\hline Culture & $57.6 \%$ \\
\hline Nature & $27.8 \%$ \\
\hline Adventure & $12.5 \%$ \\
\hline Other & $2.1 \%$ \\
\hline
\end{tabular}

In terms of gender, $59.5 \%$ of tourist guides surveyed were male, $38 \%$ were female, and $2.5 \%$ opted not to disclose. More than a third (39\%) of tourist guides were between the ages of 23 to 35 years of age, $26.5 \%$ between 46 to 64 years of age, $25.5 \%$ between the age of 36 to 45 years. A small portion $(9 \%)$ of respondents were over the age of 65 years. A third of the tourist guides $(33 \%)$ reside in Johannesburg Metropolitan, 20.5\% in Tshwane Metropolitan, 16.5\% in Ekurhuleni Metropolitan, 16\% in the West Rand District Municipality, and 14\% in the Sedibeng District Municipality. A large portion (42\%) of tourist guides surveyed were in possession of an undergraduate degree. The highest educational qualification of 35\% of guides was a senior certificate, followed by $11 \%$ qualified with a post-graduate degree and $10 \%$ without any formal qualification. A small portion of tourist guides $(1.5 \%)$ indicated otherwise. Over a third of respondents $(38.5 \%)$ have between 5 and 10 years of career experience as a tourist guide, followed by $26 \%$ of tourist guides having more than 10 years of experience. Collectively, $35.5 \%$ of tourist guides have between 1 to 5 years of career experience, indicating their relative newness in the profession. This could also be indicative of the different types of support that tourist guides may require, especially in the face of crisis within the sector, but also in terms of continuous professional development and training for the longevity of their careers. The majority of tourist guides $(67.5 \%)$ who participated in this study were self-employed or worked on a freelance basis, with only $19 \%$ of guides holding full-time employment, as indicated in Table 2 above. Additionally, $13.5 \%$ of tourist guides were employed on a part time or casual basis. Within the South African context, 
people who are self-employed have significant financial commitments apart from business operations, including paying for private healthcare plans (medical aid) and investing in policies for their future and retirement. Those who are employed on a full-time basis often have access to these benefits as part of their remuneration packages, thus providing some insulation during strenuous times (Nyawo, 2020). For tourist guides who are self-employed or employed on a part time or casual basis, these are the first costs that are reduced when cash flow is strained. This was unsurprisingly mentioned by a key stakeholder interviewed, who reiterated the financial vulnerability of tourist guides. This vulnerability is worsened in the case of casually employed guides, whose limited employment reduced to nil with the shrinkage of demand for their services, ultimately stemming from the COVID-19 induced pandemic.

"Most guides don't have a retirement annuity, they don't have a pension plan, they're very much day to day income earners. So, if they don't work for a month, the next month they don't have anything to go with [to buy] the bread or pap as basics. They don't have a backup and that means that most of the guides at the moment are going through a very tough spot" - Key informant 1 .

All tourist guides surveyed were qualified with either an NQF $2(32 \%)$ or an NQF $4(67 \%)$. This is in line with the national requirements set forth by the NDT (NDT, 2021). Tourist guides surveyed were either provincial guides (39.1\%), site guides $(32.6 \%)$, or national guides $(28.3 \%)$, with the majority (57.5) being classified as cultural guides, $27.8 \%$ as nature guides, and $12.5 \%$ as adventure guides.

\section{COVID-19 and the impact on tourist guides: bookings, cash flow, and support programmes}

The classifications above are aligned with the classification of popular tourist offerings in South Africa, with cultural, nature based and adventure tourism being popular (Leonard and Langton, 2016; Tseane-Gumbi and Ani, 2019). The bookings that tourist guides experienced after the onset of the COVID-19 induced pandemic drastically reduced compared to the prepandemic era, as shown in Table 3 below. Approximately $69.3 \%$ of tourist guides' collective bookings were cancelled with a partial or full refund. Similarly, approximately $63.6 \%$ of bookings were cancelled with no refund. There was a significant percentage of bookings $(55.6 \%)$ that were deferred to a later date. This was promising, indicating that tourists' confidence in travel and tourism activities was not completely diminished, thus maintaining a level of demand for tourist guides. However, it is important to note that this data was collected in the first half of 2021. The country has since experienced fluctuations in the lockdown levels, as well as in the reopening and closure of the tourism sector (see Smith, 2021a; Daniel, 2021). Most recently, the December tourism peak season in the country, which was critical to igniting demand once again, has been put on hold due to increasing infection numbers, a new strain of the virus, and consequent international travel bans (see Smith, 2021b). Ultimately, this has an effect on tourist willingness to constantly reschedule or defer bookings, with many opting for refunds given the uncertainty within the industry. The negative impact that this situation has had on tourist guides is further demonstrated in Table 3 below, which details the effect that this crisis has on their working conditions.

Table 3. Effects on bookings (in\%) $(\mathrm{n}=200)$

\begin{tabular}{|l|l|c|c|c|c|c|}
\hline V\# & \multicolumn{1}{|c|}{ Effects on bookings } & $\begin{array}{c}\text { Applied to } \\
\text { no booking }\end{array}$ & $\begin{array}{c}\text { Applied to 1- } \\
\text { 25\% of bookings }\end{array}$ & $\begin{array}{c}\text { Applied to 26 - } \\
\mathbf{5 0 \%} \text { of bookings }\end{array}$ & $\begin{array}{c}\text { Applied to 51- } \\
\mathbf{7 5 \%} \text { of bookings }\end{array}$ & $\begin{array}{c}\text { Applied to 76 - } \\
\text { 100\% of bookings }\end{array}$ \\
\hline V1 & $\begin{array}{l}\text { Existing bookings were cancelled with } \\
\text { either full or partial refund }\end{array}$ & $30.7 \%$ & $10.4 \%$ & $6.8 \%$ & $7.8 \%$ & $44.3 \%$ \\
\hline V2 & $\begin{array}{l}\text { Existing bookings were cancelled with } \\
\text { no refund }\end{array}$ & $36.4 \%$ & $19.0 \%$ & $14.9 \%$ & $6.2 \%$ & $23.6 \%$ \\
\hline V3 & $\begin{array}{l}\text { Existing bookings were deferred to be } \\
\text { taken up at a later date }\end{array}$ & $44.4 \%$ & $28.1 \%$ & $10.7 \%$ & $5.6 \%$ & $11.2 \%$ \\
\hline
\end{tabular}

Table 4. Effects on working conditions (in\%) (n=200)

\begin{tabular}{|l|l|l|l|l|l|l|}
\hline V\# & Effects on working conditions & Declined completely & Declined significantly & Declined a little & Did not change & Increased \\
\hline V1 & New bookings & $61.6 \%$ & $25.8 \%$ & $9.1 \%$ & $3.0 \%$ & $0.5 \%$ \\
\hline V2 & My working hours & $56.3 \%$ & $34.0 \%$ & $5.6 \%$ & $3.6 \%$ & $0.5 \%$ \\
\hline V3 & My income generation opportunities & $57.3 \%$ & $36.2 \%$ & $5.0 \%$ & $1.5 \%$ & $0.0 \%$ \\
\hline
\end{tabular}

New bookings, working hours, and income generation opportunities for tourist guides surveyed had almost completely declined since the onset of this pandemic. The sharp decline in new bookings is reflective of the closures within the tourism sector, with many businesses not being able to operate or receive a full complement of guests under the various lockdown restrictions. This decline is also reflective of tourists' uncertainty with regard to engaging in tourism activities. This uncertainty is not only linked to health and safety concerns but also to financial concerns and whether or not they stand to lose out if travel plans are halted again. This concern stems from the fact that many people have been financially impacted since the onset of the pandemic (Bama and Nyikana, 2021). As shown in Table 4, most concerning is that $98.5 \%$ of tourist guides surveyed indicated that their income generating activities declined, with just $1.5 \%$ indicating that there was no change. The decline in income generating opportunities is directly linked to the survival of tourist guides and their resilience capacity. The extent to which tourist guides' income was disrupted is illustrated in Table 5, which indicates that $94.5 \%$ of tourist guides income was severely or completely disrupted. These results, when considered with the fact that the majority of these tourist guides are self-employed or freelance guides, does not bode well for their survival during the current crisis (Nyawo, 2020). The likelihood of survival also diminishes as the crisis becomes more prolonged and the 
mechanisms that tourist guides used to support themselves become exhausted. The prolonged nature of the pandemic and its consequence for tourist guides was noted by a key informant interviewed.

"I thought that this year January I will be back at about 15\% recovery, and this year February I'm still at 0\% recovery. So I'm already 15\% behind my estimate in year one, and I was expecting to be at about $60 \%$ in September 2021. I don't think I'm going to be at 60\% in September 2021. In September 2021 I might be at 15\% if I'm lucky, so I was expecting full recovery by September 2022 that now shifts to 2023 and I can't wait until September 2023 to start earning money. It's just not possible and most guides are worse off than that." - Key informant 1 .

Table 6. Tourist guides benefitting from financial support programmes (in\%) $(n=200)$

Table 5. Effects cash flow (in\%) $(\mathrm{n}=200)$

\begin{tabular}{|c|c|}
\hline Effects cash flow & \% (n= 200) \\
\hline Was completely disrupted & 66.0 \\
\hline Was severely disrupted & 28.5 \\
\hline Was a little disrupted & 5.0 \\
\hline Did not change & 0.5 \\
\hline
\end{tabular}

\begin{tabular}{|c|l|l|l|c|}
\hline V\# & \multicolumn{1}{|c|}{ Programme } & \multicolumn{1}{c|}{ No } & \multicolumn{1}{c|}{ Yes } & Don't know \\
\hline V1 & Tourism Relief Fund & $48.3 \%$ & $48.3 \%$ & $3.3 \%$ \\
\hline V2 & IDC Support Funding & $88.8 \%$ & $3.4 \%$ & $7.8 \%$ \\
\hline V3 & Tax relief & $84.0 \%$ & $5.0 \%$ & $10.9 \%$ \\
\hline V4 & TERS & $81.5 \%$ & $13.4 \%$ & $5.0 \%$ \\
\hline V5 & SMME support intervention & $89.1 \%$ & $5.9 \%$ & $5.0 \%$ \\
\hline V6 & Social Relief and Economic Support Package & $87.4 \%$ & $4.2 \%$ & $8.4 \%$ \\
\hline V7 & COVID 19 Loan Guarantee Scheme & $87.4 \%$ & $4.2 \%$ & $8.4 \%$ \\
\hline V8 & South African Future Trust & $94.1 \%$ & $0 \%$ & $5.9 \%$ \\
\hline
\end{tabular}

A key informant interviewed reinforced the consequences of disrupted cash flow for tourist guides and provided an insight into the impact of canceled bookings. This highlights the dependence of their livelihood on month-to-month income (De Beer, 2011), as well as on the sound functioning of the tourism sector as a whole.

"On the financial side of things, I think tourist guides suffered the most the moment COVID hit. As you know, they might have just finished the tourism peak season (December/January) and into lockdown (March last year). The reality that they all had to face was the lack of income, as many tour bookings were cancelled" - Key informant 2.

In an attempt to try and supplement tourist guides' lost income, there were a variety of financial support programmes underwritten by the government, available (in theory) to tourist guides. Some of these programmes included the Tourism Relief Fund, with an amount of this fund dedicated to tourist guides specifically, IDC Support funding, tax relief, SMME support, TERS, and others. It is evident from Table 6 below that apart from the Tourism Relief Fund (V1), tourist guides largely did not benefit from the financial support programmes as intended. Although aimed at providing short term relief for tourist guides (NDT, 2021), most of these programmes did not assist tourist guides in times of crisis, nor did these programmes contribute towards building resilience. These sentiments are further elaborated in Table 7 below, where tourist guides' perceptions of the government support programmes are detailed. Significantly, there is a high percentage of respondents (47\%) who disagree that the government programmes met the needs and priorities of tourist guides (V1). Similarly, $51 \%$ of respondents disagreed that the government support and programmes were adequate and helpful in supporting and securing the future of tourist guides during the COVID-19 pandemic. Furthermore, just under half of all respondents indicated that the programmes were not accessible to tourist guides (V3) and that these programmes and support measures were not reaching the intended recipients (V5). The overall perception conveyed in Table 7 is generally one of dissatisfaction and apathy, indicated by the high proportions of tourist guides who disagreed or remained neutral on the statements posed. This is especially concerning, having implications for the future of the tourist guiding profession. The resources needed by tourist guides to survive the current crisis supersedes what is available and accessible. If unable to survive until the long-term reopening of the sector, not only does it have a major negative impact on the livelihood of tourist guides, but it also has a major impact on the supply of this particular service in the tourist sector. As a key informant discussed, tourist guides need to undergo training and must possess certain skills to practice. This is not a job that anyone can do - it takes knowledge, diversity of skills, and dedication to the job.

Table 7. Tourist guides perception of the COVID-19 government tourism

SMMEs support programmes and relief measures for tourist guides (in\%) $(n=200)$

\begin{tabular}{|c|c|c|c|c|c|}
\hline V\# & $\begin{array}{c}\text { Tourist guides perception of the COVID-19 government } \\
\text { tourism SMMEs support programmes and relief measures for tourist guides }\end{array}$ & Disagree & Neutral & Agree & $\begin{array}{l}\text { Don't } \\
\text { know }\end{array}$ \\
\hline V1 & $\begin{array}{l}\text { I am satisfied that government business support programmes meet the needs, interests, and } \\
\text { priorities of tourist guides }\end{array}$ & $47 \%$ & $27 \%$ & $20 \%$ & $6 \%$ \\
\hline V2 & $\begin{array}{l}\text { I am satisfied that tourism business support programmes offered by government authorities } \\
\text { were adequate and helpful in supporting and securing the future of tourist guides during the } \\
\text { COVID-19 pandemic }\end{array}$ & $51 \%$ & $24 \%$ & $16 \%$ & $9 \%$ \\
\hline V3 & $\begin{array}{l}\text { I am satisfied that government tourism business support programmes offered by government } \\
\text { authorities are accessible to all SMMEs and tourist guides }\end{array}$ & $46.3 \%$ & $25.6 \%$ & $15.6 \%$ & $12.6 \%$ \\
\hline V4 & I am satisfied with the tourism business support programmes offered by government authorities & $47.5 \%$ & $26 \%$ & $16 \%$ & 0.5 \\
\hline V5 & $\begin{array}{l}\text { I am confident that the business support programmes offered by government authorities are } \\
\text { reaching the intended recipients }\end{array}$ & $44 \%$ & $23 \%$ & $14 \%$ & $19 \%$ \\
\hline V6 & $\begin{array}{l}\text { Government has provided leadership and made the right decisions in assisting SMMEs and } \\
\text { tourist guides to survive the impact of COVID-19 }\end{array}$ & $45.5 \%$ & $21 \%$ & $20.5 \%$ & $13 \%$ \\
\hline
\end{tabular}




\section{Survival mechanisms employed by tourist guides during COVID-19}

To try and temper some of the extreme negative consequences of the disruptions to careers and livelihoods, tourist guides had indicated some of the ways that they tried to adapt, as well as some of the strategies that they put in place to try and stay afloat. Table 8 below details some of the short-term mitigation and survival actions taken by the tourist guides surveyed. Across all variables, there was a significant portion of tourist guides who did not take any of these actions. Of those who did, amending their cancellations and refunds policy (V1), supplementing income with other skills, knowledge, or alternate employment (V4 and V5), selling personal possessions or securing financial loans to keep their businesses afloat (V8 and V9) and drawing on government financial relief (V5) seemed to be short term measures that were relatively successful, although detrimental in the long term. Key informants interviewed elaborated on this, stating

"Quite a few guides took up any job they could find in any sector just to be able to have some income. I don't think it was a matter of preference or anything, it was just a need to earn a living and put food on the table, and whatever job they could secure to bring in that additional income they were doing that" - Key informant 2.

"My wife and I had corporate careers before, so we've cashed in retirement annuity so as to pay for bond and safari car, and which is why we can actually dedicate time to tourist guide association work because we're living off our retirement annuity. But most guides don't have a retirement annuity, they don't have a pension plan, they're very much day to day income earners" - Key informant 1.

"Many indicated that when tourists guiding fell away due to restrictions took odds and ends to earn some income. One of the guides just took on a job like a handyman. He just advertised himself as being able to do all sorts of other things. Another went to help in the family engineering business although he's not an engineer. Also, some of the ladies that I spoke to who are tourist guides, went into the catering business" - Key informant 4.

Although the South African government offered support programmes for stakeholders in the tourism sector (see NDT, 2021), with a relief fund set up specifically for tourist guides, the impact of these programmes seems to be minimal, with only $37.4 \%$ of tourist guides surveyed having accessed these funds with varying levels of success. On this specific measure, many tourist guides indicated that they were unable to access the funding support due to administrative requirements which they were unable to meet, which a key informant also explained:

I applied for the TRF because we had the paperwork required for application. But when I look at the way a lot of guides operate, I realised most of them wouldn't have tax clearance certificates, 6 months bank statements signed and stamped, and other paperwork required to complete the application" - Key informant 1.

Furthermore, the conditions of access barred some from applying for the funds at all (see Plasket, 2021; Girma, 2021; Masihlelo, 2020). For those that were able to access the funds, although providing a small amount of relief, it was not adequate to support these guides' livelihoods throughout an extremely volatile crisis.

Table 8. Short term mitigation and survival actions (in\%) $(\mathrm{n}=200)$

\begin{tabular}{|c|c|c|c|c|}
\hline $\mathbf{V} \#$ & Short term mitigation and survival actions & $\begin{array}{c}\text { Did not } \\
\text { take action }\end{array}$ & $\begin{array}{l}\text { Took action, not } \\
\text { at all successful }\end{array}$ & $\begin{array}{c}\text { Took action with } \\
\text { varied levels of success }\end{array}$ \\
\hline $\mathrm{V} 1$ & $\begin{array}{l}\text { (I/the company I work for) amended cancellations and refunds policy to allow } \\
\text { deferment of tour bookings instead of cancellations }\end{array}$ & $44.1 \%$ & $16.4 \%$ & $35.9 \%$ \\
\hline $\mathrm{V} 2$ & $\begin{array}{l}\text { (I/the company I work for) introduced advance pre-payment policy structure } \\
\text { for tourist guiding bookings to acquire much needed income and cash flow to } \\
\text { sustain operations }\end{array}$ & $52.1 \%$ & $17.0 \%$ & $27.8 \%$ \\
\hline V3 & $\begin{array}{l}\text { (I/the company I work for) generated income from providing virtual tours } \\
\text { using my/their digital skills (IT and communication and social media) }\end{array}$ & $66.8 \%$ & $10.7 \%$ & $21.4 \%$ \\
\hline $\mathrm{V} 4$ & $\begin{array}{l}\text { I generated supplementary income by using my other entrepreneurial skills } \\
\text { and knowledge (sales and marketing, financial, customer service) to provide } \\
\text { other business and individual service }\end{array}$ & $19.0 \%$ & $23.5 \%$ & $46 \%$ \\
\hline V5 & I took a temporary job as an interim measure to augment the lost income & $34.5 \%$ & $18.0 \%$ & $36 \%$ \\
\hline V6 & $\begin{array}{l}\text { (I/the company I work for) secured government financial relief support to } \\
\text { supplement income lost }\end{array}$ & $40.0 \%$ & $14.4 \%$ & $37.4 \%$ \\
\hline V7 & $\begin{array}{l}\text { I used the supplementary income generated from my other productive } \\
\text { activities to support and secure the future of my tourist guiding operation }\end{array}$ & $49.2 \%$ & $15.9 \%$ & $26.6 \%$ \\
\hline V8 & $\begin{array}{l}\text { I sold personal assets acquired through my career as a tourist guide to } \\
\text { generate the financial resources needed to support and secure the future of my } \\
\text { tourist guiding operation }\end{array}$ & $50.5 \%$ & $10.5 \%$ & $35.5 \%$ \\
\hline V9 & $\begin{array}{l}\text { (I/the company I work for) borrowed money (from bank, family, and friends) } \\
\text { and re-invested funds in tourist guide operations to ensure survival }\end{array}$ & $49.0 \%$ & $10.5 \%$ & $36.5 \%$ \\
\hline
\end{tabular}

In addition to the short term, more immediate mitigation and survival mechanisms that were actioned by tourist guides, there was also a host of medium to long term actions taken aimed at mitigation and resilience building. Of these measures, the improvement of digital skills and knowledge to build capabilities for tourist guiding services seemed to be the strategy with a high level of success amongst respondents (see V2 in Table 8). The other strategy that was adopted by most respondents and that yielded the most success was cost cutting measures within households, with a view to direct any extra financial capacity towards the future of the tourist guide's career or business (V6). 
Cost cutting measures seemed to be the first strategy that many tourist guides adopted for both short and medium to long term goals. Linked to this, some tourist guides indicated that they either temporarily closed down operations (V8) or, if they were business owners, that they had to retrench some of their employees as a cost cutting measure (V10). Ultimately, most of these measures and strategies are aimed at either saving money or trying to generate income from alternative methods to try and make up for the steep shortfall from the lack of opportunity to practice tourist guiding. It is interesting to note that only $34.4 \%$ of respondents were successful to varying extents in benefitting from government nonfinancial business support and that only $39.1 \%$ joined industry associations as a support structure and to try and build resilience for their businesses/careers. A key stakeholder interviewed provided an insight into the tourist guides' membership to industry organisations. Although a good source of support, continuous development, and networking opportunities, many tourist guides have had to cancel or opt for nonrenewal of their annual membership fees, owing to the significant reduction in their cash flow. The lack of employment and tourist guiding opportunities, coupled with their cost cutting survival measures did not leave room for the payment of membership fees to a tourist guiding organisation, especially when not being given the opportunity to engage in guiding.

“... we also have other tourist guides that did phone and say, look, my registration has expired I am not going to come to register now simply because I am going to waste my registration time and money. So we're going to monitor the industry and see how things change and improve and based on that, we're going to come back to register when the tourists start coming back to the country" - Key informant 5.

"I think obviously the number of tour guides re-registered this year is probably a record low because many of them I'm sure are simply out of a job to put it bluntly" - Key informant 5.

Table 9. Medium to long term mitigation actions (in\%) (n=200)

\begin{tabular}{|c|l|c|c|c|}
\hline V\# & \multicolumn{1}{|c|}{ Medium term mitigation action and resilience building actions } & $\begin{array}{c}\text { Did not } \\
\text { take action }\end{array}$ & $\begin{array}{c}\text { Took action, not } \\
\text { at all successful }\end{array}$ & $\begin{array}{c}\text { Took action with } \\
\text { varied levels of success }\end{array}$ \\
\hline V1 & $\begin{array}{l}\text { (I/the company I work for) benefitted from government non-financial } \\
\text { business support programme aimed at building capabilities for survival and } \\
\text { resilience for tourist guiding services }\end{array}$ & $47.7 \%$ & $17.9 \%$ & $34.4 \%$ \\
\hline V2 & $\begin{array}{l}\text { I used this period to improve my digital skills and knowledge as a measure } \\
\text { to build capabilities for survival and resilience for my tourist guiding services }\end{array}$ & $22.5 \%$ & $12.0 \%$ & $65.5 \%$ \\
\hline V3 & $\begin{array}{l}\text { I used this period to launch and expand digital media presence as a } \\
\text { mechanism to improve my relationship with customers and leverage } \\
\text { increased future bookings for my tourist guiding services }\end{array}$ & $36.5 \%$ & $18.5 \%$ & $45 \%$ \\
\hline V4 & $\begin{array}{l}\text { (I/the company I work for) started offering lower prices as a measure to } \\
\text { increase demand for tourist guide services }\end{array}$ & $47.0 \%$ & $19.2 \%$ & $33.8 \%$ \\
\hline V5 & $\begin{array}{l}\text { (I/the company I work for) offered alternative products to increase demand } \\
\text { for tourist guide services }\end{array}$ & $52.6 \%$ & $13.8 \%$ & $33.8 \%$ \\
\hline V6 & $\begin{array}{l}\text { I restricted spending on non-essential household expenditures and redirected } \\
\text { savings towards supporting and securing the future of my tourist guiding operation }\end{array}$ & $14.2 \%$ & $7.6 \%$ & $78.2 \%$ \\
\hline V7 & $\begin{array}{l}\text { I joined industry association/s as a support structure to build capabilities for } \\
\text { survival and resilience for my tourist guiding operation }\end{array}$ & $46.7 \%$ & $14.2 \%$ & $39.1 \%$ \\
\hline V8 & (I/the company I work for) temporarily closed the operations & $31.5 \%$ & $11.7 \%$ & $56.8 \%$ \\
\hline V9 & (I/the company I worked for) permanently closed the operation & $62.2 \%$ & $9.2 \%$ & $28.5 \%$ \\
\hline V10 & (I/the company I work for) laid off some employees to remain financially viable & $40.6 \%$ & $8.6 \%$ & $50.5 \%$ \\
\hline
\end{tabular}

These concerns were echoed by a key informant interviewed, who alluded to the vulnerability of freelance tourist guides due to the absence of a formal salary. Additionally, even those guides who earn a fixed income have taken up alternative employment to secure themselves financially.

"I know one guy that's now got a catering company. He's Italian well Italian/South African but he does the Italian market and the German market, but he can cook. So he started making nice little delicacies and selling them through one of those I mean little shops, you know, the ones that get into centres that sell little cookies and stuff. And then he expanded and now sells lasagnas and cannelloni's ready to freeze, and they're really good I mean two main portions, the kind that you would buy at Pick n' Pay or Spar but homemade and cheaper and all natural ingredients. So that's what he's doing to survive the pandemic' - Key informant 1.

"There is a lady who is now offering Spanish classes, [and] she's become a teacher. She's not a qualified teacher, but she's teaching people to speak the language, so that they can communicate in the language. We also know somebody that's doing Italian, we know people that have now turned their homes into, sort of like, bed and breakfast type establishments but not for guests but for people that no longer can afford a home, so if you can't afford the rent, come and stay with me and we split the rent that kind of thing"-Key informant 3

"There are guides now doing deliveries for Amazon and Takealot with their own vehicles. Other guides with heavy duty licenses now driving trucks and others doing call centre work" - Key informant 1.

Concerns around the finances are unfortunately not unique to tourist guides in the current time and has been noted to be a 
common concern among tourists and tourism stakeholders since the onset of the pandemic. This is owed to widespread job losses, retrenchments, reduction in salaries and working hours (Bama and Nyikana, 2021; Nyawo, 2020; Chirisa et al., 2020).

\section{CONCLUSION AND RECOMMENDATIONS}

Reflecting on the foregoing discussion, it is evident that tourist guides were heavily impacted from the onset of the pandemic and the institution of national lockdown levels in the country. Tourist guides are arguably among the most significantly impacted role-players in the tourism sector, having already been a precarious and somewhat unsecured financial position pre-pandemic. The absence of employment security and financial insulation translated to service providers, who, although integral to the smooth functioning of the destination, were vulnerable to crises such as this.

Consequently, it has emerged that many tourist guides do not have a lot of capacity to weather prolonged crises such as this, with many of the guides who participated in this study living on a month-to-month basis. This speaks to the resilience of tourist guides - an important consideration in crisis management (Jones and Comfort, 2020). The government support programmes made available during this period were aimed at assisting tourism stakeholders, and specifically tourist guides through the provision of that Tourist Guide Relief Fund (NDT, 2021). Unfortunately, the rollout and uptake of the funds and other support programmes did not pan out as expected, leaving many tourist guides in a similarly vulnerable position. Significantly, given the shortcomings with the support (see Plasket, 2021; Girma, 2021; Masihlelo, 2020), many tourist guides tried to implement their own survival plans by cashing in their personal assets, taking out loans or refinancing existing ones, reducing lifestyle costs, and finding other employment to supplement their income. These plans were all aimed at the immediate survival of their careers but unfortunately eroded at their ability to withstand any more of this crisis or any other that may occur soon. Other longer-term measures instituted by tourist guides included the modification of their service policies, allowing for future booking and deferment of existing bookings, providing an array of digital tourist guiding services to try and supplement their traditional in-person tour guiding activities. Additionally, given the massive move to the online space since the beginning of this pandemic (Chirisa et al., 2020), many guides are trying to improve their online presence to try and connect with tourists, to ultimately ensure the future of their careers.

Despite these impressive efforts, the strain of the stop-start nature that the risk adjusted lockdown levels have resulted in has become overwhelming. The fluidity of the situation has resulted in shifting goalposts, testing even the most resilient and insulated stakeholders in the sector (Iastremska and Kononova, 2021; Sucheran, 2021). It is also difficult to determine at present whether these short- and longer-term measures will prove to be effective or adequate to carry tourist guides until the certain reopening of the sector, as this also remains an unknown. Given the important role that tourist guides play in the sector, it is essential that their progress and survival throughout the remainder of the current crisis is monitored, as well as the opportunities available for them to resume duty upon reopening. As previously mentioned, there is relatively little known about tourist guides within the South African context, with this lack of insight proving to be a hurdle in formulating effective plans and strategies to assist tourist guides currently. This study focused on the current COVID-19 crisis that has afflicted the tourism sector in South Africa and all tourism stakeholders. Tourist guides perform an integral role in the tourism industry, as vital role players in welcoming and interacting with tourists, providing information about a destination and its history (Collins, 2000; Ooi, 2002; Chowdhary and Prakash, 2010). Despite this crucial role, a limited amount of research has been conducted specifically on tourist guides in the South African tourism sector. The research that has been done focuses on the development and training of tourist guides and the employment conditions that tourist guides work within (see Davids, 2008; Gavron, 2002; McIntyre, 2007, Rogerson, 2004; Rogerson and Visser, 2004).

Thus, the contribution of the present study is two-fold, contributing to the theoretical discourse on tourist guides within the South African context, as well as within a tourism crisis context. More specifically, the current study investigated some of the common survival mechanisms that tourist guides utilize in times of crisis. Additionally, the contribution of this study is practical, as the unique and contemporary findings of this study can be used to inform the Gauteng provincial department's plans and strategies related to tourist guides. Furthermore, given the lack mentioned above of research on tourist guides in South Africa and the various issues that they face, this study can serve as a baseline for future studies, especially in respect of investigating the impacts of the support measures offered to and utilised by tourist guides in the long term. Such studies may provide insight into how the measures instituted, and programmes offered contributed to the ability of tourist guides to survive in times of crisis and towards increasing their overall capacity towards resilience. Although these are issues that the current study has touched on, there is scope for further research given that the pandemic is still ongoing, thus the full impact can be assessed post-crisis. This baseline for further research is especially important considering the various crises that can afflict the sector. Preparing for crisis within the sector is an integral aspect of crisis management and resilience building, which should form part of the research agenda going forward.

The findings of this study revealed the need for further research on tourist guides and the issues they contend with in the South African context. As this is an ongoing crisis that is constantly changing, ongoing monitoring and evaluation of the situation is imperative. Additionally, the results point to preliminary areas for policy and organisational improvement related to the government support mechanisms available to tourist guides, as well as the administrative requirements for the mechanisms. Moreover, future research on tourist guides within the current and eventual post COVID-19 context is required to quantify the number of tourist guides that have survived the COVID-19 pandemic, including an analysis of the type of support the tourist guides require to adapt and innovate their offerings is necessary.

Other recommendations from this study include that a proactive risk management plan at an organisational (i.e., tourist guide) and industry level must be developed as a resilience measure to minimise the impact of future tourism crises in the sector. A focus on building resilience into the overall tourism sector and businesses need to be a priority, as 
support measures are often finite and can become an unsustainable or unfeasible practice. Additionally, as evidenced from the current situation, the support measures and programmes offered can be problematic when not available to all affected, or when there is a lack of communication and understanding about them. Hence, building resilience should be an integral aspect of recovery going forward and planning for future crises.

\section{REFERENCES}

Bama, H.K.N., \& Nyikana, S. (2021). The effects of COVID-19 on future domestic travel intentions in South Africa: A stakeholder perspective. African Journal of Hospitality, Tourism and Leisure, 10(1), 179-193. https://doi.org/10.46222/ajhtl.19770720-94

Brouder, P. (2020). Reset redux: possible evolutionary pathways towards the transformation of tourism in a COVID-19 world. Tourism Geographies, 22(3), 484-490. https://doi.org/10.1080/14616688.2020.1760928

Brouder, P., Teoh, S., Salazar, N.B., Mostafanezhad, M., Pung, J.M., Lapointe, D., Higgins Desbiolles, F., Haywood, M., Hall, C.M., \& Clausen, H.B. (2020). Reflections and discussions: tourism matters in the new normal post COVID-19. Tourism Geographies, 22(3): 735-746. https://doi.org/10.1080/14616688.2020.1770325

BusinessTech (2021). Ramaphosa extends lockdown level 3 in South Africa - with some changes to restrictions. [Accessed on 28 February 2021]. https://businesstech.co.za/news/government/460054/ramaphosa-extends-lockdown-level-3-in-south-africa-withsome-changes-to-restrictions/

Cahyanto, I., \& Pennington-Gray, L. (2017). Toward a comprehensive destination crisis resilience framework. Travel and Tourism Research Association: Advancing Tourism Research Globally. 21. https://scholarworks.umass.edu/cgi/viewcontent.cgi?article=2047\&context=ttra

Chen, H., Weiler, B., \& Black, R. (2018). Exploring knowledge-building in tour guiding research: A content analysis of empirical papers on tour guiding, 1980-2015. Journal of Hospitality and Tourism Management, 37, 59-67. https://doi.org/10.1016/j.jhtm.2018.09.005

Chilembwe, J.M., \& Mweiwa, V. (2014). Tour guides: Are they tourism promoters and developers? Case study of Malawi. International Journal of Research in Business Management, 2(9), 29-46.

Chirisa, I., Mutambisi, T., Chivenge, M., Mbasera, M., Sidambe, M., Muchenje, B., Mukwashi, T., Mabaso, E., Ncube, R., \& Zengeni, D. (2020). Scope for virtual tourism in the times of COVID-19 in select African destinations. Journal of. Social Science, 64(1-3). https:////doi.org/10.31901/24566756.2020/64.1-3.2266

Chowdhary, N., \& Prakash, M. (2010). Tour Guiding in India: A Case Study. European Journal of Tourism and Research, 3(1), 67 - 84.

Collins, V.R. (2000). Becoming a Tour Guide: The Principles of Guiding and Site Interpretation. London and New York: Continuum.

Creswell, J.W., \& Creswell, D.J. (2018). Research Design: Qualitative, Quantitative, and Mixed Methods Approaches, Sage, Washington, DC.

Daniel, L. (2021). South Africa tourism responds to UK travel ban. Business Insider. https://www.businessinsider.co.za/south-africatourism-responds-to-uk-travel-ban-2021-11

Davids, E. (2008). A theoretical analysis of the development of tourist guiding in South Africa. Masters Thesis. Cape Peninsular University of Technology.

Davidson, S. (2021). The world wants to reopen: will vaccine passes be the key? Biometric Technology Today, 2021(6), 5-7. https://doi.org/10.1016/S0969-4765(21)00070-9

De Beer, A. (2011). Employment Conditions in the South African Tourism Industry: An Analysis of Tourist Guides. Masters thesis, University of Witwaterstrand.

De Beer, A., Rogerson, C.M., \& Rogerson, J.M. (2014). Decent Work in the South African Tourism Industry: Evidence from Tourist Guides. Urban Forum, 25, 89-103. DOI 10.1007/s12132-013-9199-8

Dube, K. (2020). Tourism and sustainable development goals in the African context. International Journal of Economics And Finance Studies, 12(1), 88-102. https://doi.org/10.34109/ijefs.202012106

Feldman, J., \& Skinner, J. (2018). Tour Guides as Cultural Mediators. Ethnologia Europaea, 48(2), 5-13.

Gavron, M. (2002). The contradictions and contestations in policy production and elaboration of policy for the training of tourist guides in South Africa. Masters Thesis. University of Cape Town.

Girma, L.L. (2021). South Africa Launches Historic Tourism Equity Fund That May Serve as Global Model. Accessed on 16 October 2021. https://skift.com/2021/02/19/south-africa-launches-historic-tourism-equity-fund-that-may-serve-as-global-model/

Gössling, S., Scott, D., \& Hall, C.M. (2020). Pandemics, tourism and global change: a rapid assessment of COVID-19. Journal of Sustainable Tourism, 29(1), 1-20. https://doi.org/10.1080/09669582.2020.1758708

Seyfi, S., Hall, C.M., \& Shabani, B. (2020). COVID-19 and international travel restrictions: The geopolitics of health and tourism. Tourism Geographies. https://doi.org/10.1080/14616688.2020.1833972

Hall, C.M., Scott, D., \& Gössling, S. (2020). Pandemics, transformations and tourism: be careful what you wish for. Tourism Geographies. https://doi.org/10.1080/14616688.2020.1759131

Helble, M., Park, C.Y., \& Won, H.C. (2021). Can Vaccination Help Restart Tourism? https://www.adb.org/sites/default/files/publication/ 723046/adb-brief-186-vaccination-help-restart-tourism.pdf. DOI: http://dx.doi.org/10.22617/BRF210321-2

Henderson, J.C. (2020). Managing Tourism Crises. Butterworth-Heinemann.

Hu, W. (2007). Our Guides and Sustainable Development: The Case of Hainan, China. PhD. University of Waterloo.

Hu, W., \& Wall, G. (2013). Tour guide management in Hainan, China: Problems, implications and solutions. Asia Pacific Journal of Tourism Research, 18(3), 205-219. https://doi.org/10.1080/10941665.2011.640699

Huang, S., Hsu, C.H., \& Chan, A. (2010). Tour guide performance and tourist satisfaction: A study of the package tours in Shanghai. Journal of Hospitality \& Tourism Research, 34(1), 3-33. https://doi.org/10.1177/1096348009349815

Iaquinto, B.L. (2018). A mixed methods approach in tourism research. In Qualitative methods in tourism research: Theory and practice, 224-247. Edited by Hillman, W. \& Radel K., Bristol, Channel View.

Iastremska, O., \& Kononova, O. (2021). Forecasting of the tourism industry development and the COVID-19 pandemic consequences: geographical and international orientation. Three Seas Economic Journal, 2(2), 54-61. https://doi.org/10.30525/2661-5150/2021-2-9

Jones, P., \& Comfort, D. (2020). The COVID-19 Crisis, Tourism and Sustainable Development. Athens Journal of Tourism, 7(2), 75-86. https://doi.org/10.30958/ait.7-2-1

Kaewkitipong, L., Chen, C., \& Ractham, P. (2021). Examining Factors Influencing COVID-19 Vaccine Tourism for International Tourists. Sustainability, 13(22), 12867. https://doi.org/10.3390/su132212867

Kim, M.J., Bonn, M., \& Hall, C.M. (2021). What influences COVID-19 biosecurity behaviour for tourism? Current Issues in Tourism: 17. https://doi.org/10.1080/13683500.2021.1883558

Levine, S. (2014). Assessing resilience: why quantification misses the point, Humanitarian Policy Group. Overseas Development Institute, Accessed on 20 September 2020. http://www.odi.org/sites/odi.org.uk/files/odi-assets/publications-opinion-files/9049.pdf 
Leonard, L., \& Langton, A. (2016). Challenges facing tourist attractions due to acid mine drainage in the West Rand, Gauteng. African Journal of Hospitality, Tourism and Leisure, 5(1), 1-12.

Masihlelo, B. (2020). More challenges delay payment relief to tourist guides. https://www.tourismupdate.co.za/article/more-challengesdelay-payment-relief-tourist-guides

McIntyre, P. (2007). South African tourist guides: An enquiry in their status in employment. Masters Thesis, University of Cape Town.

Neuendorf, K.A. (2017). The content analysis guidebook. Sage.

Nunkoo, R. (2018). Handbook of research methods for tourism and hospitality management. Edward Elgar Publishing.

Nyahunzvi, D.K., \& Njerekai, C. (2013). Tour guiding in Zimbabwe: Key issues and challenges. Tourism Management Perspectives, 6, 3-7. https://doi.org/10.1016/..tmp.2012.11.003

Nyawo, J.C. (2020). Evaluation of Government Responses and Measures on COVID-19 in the Tourism Sector: A Case of Tour Guides in South Africa. African Journal of Hospitality, Tourism and Leisure, 9(5), 1144-1160. https://doi.org/10.46222/ajhtl.19770720-74

Ooi, C.S. (2002). Cultural Tourism \& Tourism Cultures: The Business of Mediating Experiences in Copenhagen and Singapore; Copenhagen Business School Copenhagen Press.

Phillips, X. (2020). South Africa VS Coronavirus: Billions already lost in tourism. The Africa Report. 3 July 2020. Accessed on: 20 May 2020. https://www.theafricareport.com/30653/south-africa-vs-coronavirus-billions-already-lost-in-tourism/

Plasket, J.A. (2021). AfriForum vs Minister of Tourism: The SCA judgment. https://www.politicsweb.co.za/documents/afriforum-vsminister-of-tourism-the-sca-judgment

Ramphele, M. (2020). Relief Fund for Tourist Guides. Special MIPTECH Meeting, PowerPoint Presentation, Accessed 11 June 2020.

Ritchie, B.W., \& Jiang, Y. (2019). A review of research on tourism risk, crisis and disaster management: Launching the annals of tourism research curated collection on tourism risk, crisis and disaster management. Annals of Tourism Research, 79: 102812. https://doi.org/10.1016/j.annals.2019.102812

Rogerson, C.M., \& Rogerson, J.M. (2021). COVID-19 and changing tourism demand: Research review and policy implications for South Africa. African Journal of Hospitality, Tourism and Leisure, 10(1), 1-21. https://doi.org/10.46222/ajhtl.19770720-83

Rogerson, C.M., \& Visser, G. (2004). Tourism and Development Issues in Contemporary South Africa. Institute of South Africa, Pretoria.

Rogerson, C.M., \& Rogerson, J.M. (2020). Covid-19 tourism impacts in South Africa: Government and industry responses. GeoJournal of Tourism and Geosites, 31(3), 1083-1091. https://doi.org/10.30892/gtg.31321-544

Rogerson, C.M. (2004). Tourism, small firm development and empowerment in post apartheid South Africa. in R. Thomas (ed). Small Firms in Tourism: International Perspectives. Amsterdam. Elsevier. 13-33.

Sharun, K., Tiwari, R., Dhama, K., Rabaan, A.A., \& Alhumaid, S. (2021). COVID-19 vaccination passport: prospects, scientific feasibility, and ethical concerns. Human Vaccines \& Immunotherapeutics, 1-4. https://doi.org/10.1080/21645515.2021.1953350

Siakwah, P., Musavengane, R., \& Leonard, L. (2019). Tourism Governance and Attainment of the Sustainable Development Goals in Africa. Tourism Planning \& Development. https://doi.org/10.1080/21568316.2019.1600160

Sigala, M. (2020). Tourism and COVID-19: impacts and implications for advancing and resetting industry and research. Journal of Business Research, 117, 312-321. https://doi.org/10.1016/j.jbusres.2020.06.015

Smal, D.J. (1997). Instructional Design for Guiding Tourists in a changed South Africa. Cape Technikon. 1-130.

Smith, C. (2021a). Tourism gutted by mass cancellations after UK red list move. Finance24. https://www.news24.com/fin24/companies/ travelandleisure/tourism-gutted-by-mass-cancellations-after-uk-red-list-move-20211126

Smith, C. (2021b). Use of BEE criteria for govt's R200m Covid-19 tourism relief is unlawful, SCA finds. Finance24. https://www. news24.com/fin24/companies/use-of-bee-criteria-for-govts-r200m-covid-19-tourism-relief-is-unlawful-sca-finds-20210922

Su, Z., Wen, J., McDonnell, D., Goh, E., Li, X., Šegalo, S., Ahmad, J., Cheshmehzangi, A., \& Xiang, Y.T. (2021). Vaccines are not yet a silver bullet: The imperative of continued communication about the importance of COVID-19 safety measures. Brain, behavior, \& immunity-health, 12. https://doi.org/10.1016/j.bbih.2021.100204

Sucheran, R. (2021). Global Impacts and Trends of the COVID-19 Pandemic on the Cruise Sector: A Focus On South Africa. African Journal of Hospitality, Tourism and Leisure, 10(1), 22-39. https://doi.org/10.46222/ajhtl.19770720-84

Tseane-Gumbi, L.A., \& Ani, K.J. (2019). Tourism and transformation in the South Africa's former homelands: lessons and implications for Africa. African Renaissance, 16 (Special Issue 3), 93-108. https://doi.org/10.31920/2516-5305/2019/sin3a6

Venkatesh, R., \& Gouda, H. (2016). Eco-tourism - planning and developmental strategies. Global Journal For Research Analysis, 5(12), $420-422$.

Wang, M., Kunasekaran, P., \& Rasoolimanesh, S.M. (2021). What influences people's willingness to receive the COVID-19 vaccine for international travel? Current Issues in Tourism. https://doi.org/10.1080/13683500.2021.1929874

Weiler, B., \& Black, R. (2015). The changing face of the tour guide: one-way communicator to choreographer to co-creator of the tourist experience, Tourism Recreation Research, 40(3) 364-378. https://doi.org/10.1080/02508281.2015.1083742

Weiler, B., \& Ham, S.H. (2001). Tour guides and interpretation. Encyclopedia of ecotourism, 549-563.

*** National Department of Tourism (NDT). (2020). Tourism Industry Survey of South Africa: COVID-19:Impact, Mitigation and the Future. Available at: https://www.tourism.gov.za/CurrentProjects/

*** Tourism_Relief_Fund_for_SMMEs/Documents/Tourism\%20Industry\%20Survey\%20of\%20South\%20Africa\%20-\%20\%20COVID19.pdf [Retrieved 31 May 2020].

*** National Department of Tourism (NDT). (2021). 2020/21 audit outcomes: AGSA briefing. Meeting summary. 09 November 2021. https://pmg.org.za/committee-meeting/33717/

*** National Department of Tourism (NDT). (2018). State of Tourism Report. https://www.tourism.gov.za/AboutNDT/Publications/ State\%20of\%20Tourism\%20Report\%202018-19.pdf

*** National Department of Tourism (NDT). (2021). Annual Report 2020/2021. https://static.pmg.org.za/tourism-annual-report-202021.pdf

*** South African Tourism (2019). Tourism Performance Report. https://live.southafrica.net/media/276660/tourism-perfomance-report2019_v12062020.pdf?downloadId=333390

*** Statistics South Africa (2021). SA tourism industry struggles amidst COVID-19 pandemic. [Accessed on: 21 June 2021]. http://www.statssa.gov.za/?p=14281

*** World Travel and Tourism Council (WTTC). (2021). South Africa 2021 Annual Research: Key Highlights. https://wttc.org/ Research/Economic-Impact/moduleId/704/itemId/204/controller/DownloadRequest/action/QuickDownload 